Golub Marković ${ }^{1}$, Marko Mihić ${ }^{2}$, Vladimir Obradović ${ }^{3}$ ${ }^{1}$ Cardboard Mill Umka, KappaStar Group, Serbia

\title{
Implementation of Project Management Concept into Industrial Energetics: Case Study in Paper Factory
}

UDC: 005.8:[338.45:620.91

005.52:005.33

DOI: 10.7595/management.fon.2015.0011

\begin{abstract}
Fuel changing is directly linked to market movements of energy sources, consequently, large companies adapt to these changes and move towards economically worthwhile strategies.

The appearance of an energy source, change or fuel production startup, is a complex investment project in the field of industrial energetics. This research paper brings a case study of transition from gas to solid fuel in the paper factory, where the factory achieved significant savings by changing the basic fuel.

In this study we applied a large number of criteria and parameters of the project management concepts (such as WBS structure, Gantt chart, SWOT analysis, criteria for settlement date, etc.).

The purpose of this study is to demonstrate and broaden the knowledge base of in the industrial and energy sectors and to show significant benefits and cost savings which occur as a result of changes of energy sources in the industry involving mass production processes.
\end{abstract}

Keywords: energy saving, industrial energy, energy projects, steam boilers, boiler fuel, project management.

\section{Introduction}

Projects are of essential importance for the success of any company, combining activities that lead to new products and services, improving procedures, administration and development of jobs. Successful projects boost sales and cut costs, improve quality, clients 'satisfaction and operating environment and also lead to other benefits. Therefore, more companies started to use project management as a basic strategy for maintaining competitiveness, increasing the number of possibilities of bringing in new values into their businesses. (Salazar-Aramayo, Rodrigues-da-Silveira, Rodrigues-de-Almeida, \& Neuma de Castro-Dantas, 2012).

On the other hand, it is well known that energy market is not stabile and often deals with price changes. According to that, big systems such as factories with processing production and other big facilities that are supplied by boiler rooms and use a certain type of fuel, need to search constantly for the most economical and profitable energy-generating product so they can cut their production costs and manage to save money.

Exploring the literature concerning this theme, the conclusion is drawn that there is not enough empirical proofs about the implementation of project management concept on projects in industrial energetics. The fact is that this type of projects is part of a constant companies 'tendency to find more profitable energygenerating products for their facilities. Unfortunately, such of projects are being realized, but a small number of companies dedicate enough time to document the experiences from those projects, towards creating a knowledge base that can be used in some projects to come, in the same or similar areas. A scientific contribution of this research is that it brings a detailed elaboration and describes projects in industrial energetics and the use of modern methods from project management in improving the knowledge base of projects from this area. A more profitable usage of energy-generating products in industry, cutting industry costs, energy saving, implementation of modern methods in project management are the main principles this research follows. 
One of the research goals is to encourage managers in this and other related areas to start to exchange experiences and to enlarge the knowledge base in this area. By broadening knowledge one improves methods and methodology of changing energy-generating products in big industries, and it will lead to accomplishment of more important benefits concerned directly to saving energy, cutting industry costs , that is, increasing the profit of an organization, etc.

In this paper we describe an example of switching from gas to solid fuel, ans the savings resulting after the completion of these projects.

The industry of paper production is a very complicated production process. It operates on steam pressure that flows through all the machines that are part of this production. This paper shows how this factory has changed its basic energy-generating product that supplies the daily needed steam through caldron which is necessary in the production process. In the beginning, this factory had gas caldron in its boiler rooms that has been in use for years supplying steam and also supplying heating through the winter season.

In the last years the gas price has been constantly rising, hence production overheads have been more expensive, which directly influences the products ' price. The research of energy-generating product market in our region has started and the conclusion is that coal is cheaper than gas. Also, the steam caldrons with coal can also supply factory with steam, at lower costs. In this case study a realistic example of changing fuel in big industry is shown, as well savings resulting upon the completion of this project.

This paper is also about the project managing concept as well as new trends in industrial energetics. This research also describes other examples of fuel changing, for example, changeover from gas to biomass. In this research it is also concluded that there are different energy-generating product markets and that their prices vary from state to state, depending on their liabilities towards certain fuel taxes/excises. Hence we deal with different types of changes of energy-generating products in industries.

Apart from the case study, this paper also shows the case study methodology, the preview of used methods, techniques and criteria during the realization of this project. As noted above, one of the most important goals of this research is the exchange of knowledge in this area; methods and techniques applied in project management in this case study are, in a certain way, a pioneer attempt in broadening the knowledge base of this projects.

\section{Industrial Energetics Trends}

Why considering fuel changes?

The first step in recognizing the forces that motivate the decision to change from coal to coal or vice versa, depends on the market price. The main forces are about regulator (both in the emission sense and as offset for the new unit), fuel costs, the age of a power plant and its needs (Kaupp, 2009).

\section{Recognizing the options}

The first step is to provide the engineer 's study towards helping to decide which options are the best for particular utilization. Among many considerable options there are the following (Kaupp, 2009):

- Changeover to fuel with the changes of current cauldron;

- Changeover to fuel for the current cauldron with the addition of the gas turbine on the current cauldron's cycle, such as adding simple cycle to the current system, re-starting or combined cycle resupplying;

- The new combined cycle in the power plant (the elemental examination) with withdrawing of the current coal factory;

- There are many reasons for the changeover of the fuel (Jr., 2008);

- The ecological reasons for air pollution reduction;

- Economic reasons, because the new fuel is cheaper;

- The old cauldron will be replaced with the new one that uses different fuel;

- The professional technical person has recommended it;

- The cauldron's fuel is no longer available. 
The goal is to cut the costs of steam formation without the growth of energy production. The decision making is based on the list of all positive and negative circumstances from the changeover to fuel, without calculating new steam costs and comparing with current costs.

The most frequent cases of fuel changeover are as follows (Jr., 2008):

1) From light to heavy fuel which is less expensive

This changeover requires a change of burner (the burning chamber) and the oil pre-warming systems. This can lead to the growth of corrosion because of a bigger amount of sulfur and ashes with cheaper heavy fuels.

\section{2) From light fuel to gas}

The economy of such changeover much depends on the comparison of fuel costs by MJ fuel energy. The gas cauldrons have a very clean burning out and lower preservation. The warmth efficiency will not as well change a lot, however, it will improve due to reducing air odds. The investment costs for the package of cauldrons with the smoking pipe are almost the same as for the gas and oil version. Sometimes the changeover is done to comply with the strict rules for air pollution control.

3) From solid fuels to heavy oil

This changeover is often made in re-utilization of solid fuel in the burning chambers. The thermal efficiency will increase considerably. The changeover reasons are the difficulties of receiving solid fuel or the management's decision about elimination of chaotic handling of supplying fuel for solid fuel cauldrons. Occasionally both fuels are being turned on. The hereditary danger is an enhanced cauldron firing.

4) The changeover from heavy fuels to solid ones

This changeover is advised only if the old cauldron is replaced by a new one, with solid fuels. Re-utilization of cauldrons for liquid fuel for solid fuel is rarely done. The thermal efficiency will be reduced and it is certainly a big mistake to reduce investment costs by buying cauldrons for solid fuel without the system for automatic charging. In this last case efficiency can be reduced from high $83 \%$ to less than $50 \%$ and thus partially eliminate the price advantage of the solid fuel.

5) The changeover of fuels by changing the size of solid fuels

The correct dimensioning of solid fuels has an express effect on the system efficiency. Specifically, in the cauldrons that are heated with coal, the focus is on correct dimensioning of coal and benefit.

6) The changeover from one to the other solid fuel

There are a lot of reasons. The complications change the content of ashes and water, fuel dimensioning too. In economic assessments it is important to be careful with the differences in costs of fuel benefit.

\section{The Research Goals}

Once the theoretical basis has been illustrated in the previous chapter, we will proceed to illustrate the main goals of this research.

The main goals of this research can be illustrated through one main hypothesis and two supporting ones:

The main hypothesis: The utilization of project management concept will contribute to more qualitative and efficient project realization in industrial energetics. The modern development of project management, i.e., its methods and criteria, will directly influence a better project planning, realization and control in this domain.

Supporting hypothesis 1 : The project evaluation in industrial energetics will directly contribute to a better acceptance of project management concept.

Supporting hypothesis 2: Using analysis and lessons learned, the database from this domain is being extended and the base for effective realization of the projects to come is being built. 


\section{The Results and Discussion: The Reconstruction of the Energetic System in the Paper Factory}

\subsection{Introduction}

The rapid development of the cauldron technique in the last decades has conditioned abrupt changes of particular constructed elements, as well as of the whole conception of the steaming cauldron, which in this state of development represents a complex of variety of devices.

Providing that in the last few years the coal has become important again, because the prices of other energy-generating products have dramatically risen, a lot of projects dealing with changeover from cauldron plants to coal, i.e., adaptation from boiler room with cauldrons to the solid fuel have been adopted. A poor energy policy, mostly illustrated as price disparity of energy-generating products and a sudden increase in price and the gas price have all made a lot of companies, especially those with production of their own, to find a new solution concerning energy sources.

Exactly because of these market movements of the energy-generating products, the companies start new projects that consist of the following main phases:

- The purchase of new/second hand coal cauldrons;

- The breakup of cauldron to coal;

- The transport from cauldron to a purchaser (a factory);

- The preparation of boiler room for the assembly of a new cauldron/cauldrons;

- The assembly of cauldron and work release of cauldron`s plants.

\subsection{The description of energy reconstruction}

To continue the whole project structure `Breakups, the transport and the assembly of cauldrons to coal ' will be illustrated, in the boiler room of the factory which deals with process production. The investment plan of the factory is focused on the change of energy system, i.e., the transition to the solid fuel (COAL) instead of former gas (TNG).

The project of dislodgment of the cauldron `s plant from the boiler room, which is dislocated in some other place in Serbia, i.e., from the boiler room outside the Serbia's boarders, represents a complex project from the industrial energetic domain. Precisely, it is about two very similar projects whose realization will go parallelly.

Cauldron 1: The cauldron 's disassembly, the transport and assembly for production of $20 \mathrm{t} / \mathrm{h}$ fired up by the coal from a place in Serbia, in the boiler room of the factory that deals with the process production in Belgrade.

Generally speaking, it is necessary to disassemble the present, old cauldron, to transport it to the factory 's site in Belgrade, and after that to assemble the cauldron in the boiler room in the factory. The cauldron is produced by 'Minel Kotlogradnja'. The basic information about the cauldron:

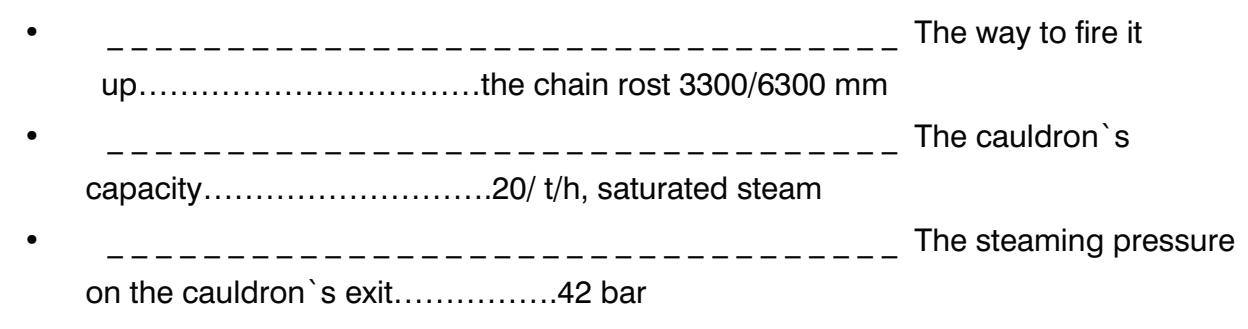




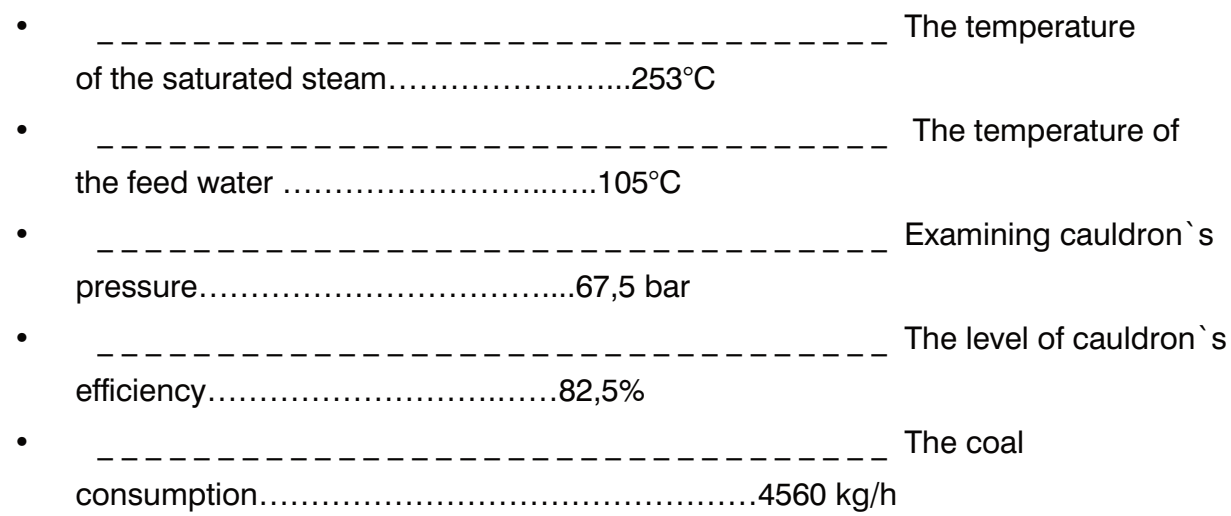

Cauldron 2: The cauldron 's disassembly, the transport and assembly for production of $10 \mathrm{t} / \mathrm{h}$ fired up by the coal from a place in Macedonia, in the boiler room of the factory that deals with the process production in Belgrade.

As already done with the first project, generally speaking, it is necessary to disassemble the present cauldron in Macedonia, to transport it to the factory 's site in Belgrade and after that to assemble the cauldron in the factory `s boiler room. The cauldron is produced by 'Djuro Djakovic'.

The information about cauldron mentioned in this documentation is the following:

- the year of production 1996

- the maximal steam production $10 \mathrm{t} / \mathrm{h}$

- the highest allowed overpressure. .12 bar

- the examining overpressure... 19 bar

- the temperature of saturated steam $192^{\circ} \mathrm{C}$

- the temperature of feed water. $105^{\circ} \mathrm{C}$

- the temperature of heated air. $150^{\circ} \mathrm{C}$

- the whole warming surface. $380,5 \mathrm{~m}^{2}$

- the content of water at the medium level......30,2 $\mathrm{m}^{3}$

- the content of steam at the medium level.....6,7 $\mathrm{m}^{2}$

- the fuel. brown coal

- assortment .0-30 mm

- the fuel consumption $2878 \mathrm{~kg} / \mathrm{h}$

The main project, adaptation of the current boiler room in the process production factory in Belgrade, is about two parallel, divided projects, which are very similar according to the their contents. One of the main goals of the boiler room 's adaptation is a significant means savings, which will succeed by transition to the solid fuel, i.e., coal.

1) Cauldron 1: The cauldron 's disassembly, the transport and assembly for production of $20 \mathrm{t} / \mathrm{h}$ fired up by the coal from a place in Serbia, in the boiler room of the factory that deals with the process production in Belgrade.

2) Cauldron 2: The cauldron ' $s$ disassembly, the transport and assembly for production of $10 \mathrm{t} / \mathrm{h}$ fired up by the coal from a place in Macedonia, in the boiler room of the factory that deals with the process production in Belgrade

The new boiler room with its work will have sufficient capacity to satisfy all the factory`s needs. 
4.3. The SWOT Analysis (Mihić, Obradović, \& Todoeovic, Economic analysis of social services for the elderly in Serbia: two sides of the same coin, 2014).

Table 3 - The SWOT analysis of the project

\begin{tabular}{|c|c|}
\hline STRENGTS & OPPORTUNITIES \\
\hline $\begin{array}{ll}\text { - } & \text { THE SUCCESSFUL, INVOLVED TEAM OF PEOPLE } \\
& \text { IN THE PROJECT } \\
\text { - } & \text { INVOLVED, STABLE SUPPLIER AND THE BEST, } \\
& \text { NEGOTIATED PRIZE } \\
\text { - } & \text { EXICTING EXPERIENCE WITH THE COAL } \\
& \text { CAULDRON } \\
\text { - } & \text { LOW FINANCING COSTS } \\
-\quad & \text { CONFIRMED AND CLEAR AIM AND THE PROJECT } \\
& \text { REAZLIZATION PLAN }\end{array}$ & $\begin{array}{ll}\cdot & \text { ACOMPLISHMENT IN SAVINGS BY TRANSITION FROM } \\
& \text { GAS TO COAL } \\
\text { - } & \text { THE SHORT PERIOD OF GAINING OF THE } \\
& \text { INVESTMENT } \\
\cdot & \text { ACOMPLISHMENT IN SAVINGS DURING NEGOTIONS, } \\
\text { INVOLVING MORE SUPPLIERS } \\
\text { USAGE OF TURBINE INSTALATION TO MAKE } \\
\text { SAVINGS IN ELECTRIC ENERGY }\end{array}$ \\
\hline $\begin{array}{ll}\text { WEAKNESSES } \\
- & \text { NOT ENOUGH EXPERIENCES IN PROJECTS IN } \\
& \text { THE INDUSTRIAL ENERGETICS } \\
\text { - } & \text { THE COMPLEX LOGISTICS OF THE SUPPLY FROM } \\
& \text { COAL TO FHB } \\
\text { - } & \text { THE COMPLEXITY OF THE PROJECT } \\
- & \text { THE AGE OF THE CAULDRONS AND EQUIOMENT } \\
- & \text { THE COAL - DIERTIER TECHNOLOGY }\end{array}$ & $\begin{array}{ll}\text { THREATS } \\
- & \text { UNPLANNED PROLONGATION OF THE PROJECT } \\
& \text { REALIZATION } \\
- & \text { THE BOOST OF ADDITIONAL COSTS OF THE } \\
& \text { INVESTMENT } \\
\text { - } & \text { AFTER CAULDRONS INSTALATION, THE TECHNICAL } \\
& \text { DEFAULTS ARE BEING DISCOVERED } \\
- & \text { THE BOOST OF COAL COSTS } \\
- & \text { ECOLOGICAL LICENCE } \\
- & \text { THE FILTER COSTS }\end{array}$ \\
\hline
\end{tabular}

4.4.The defining of the WBS project phase

Table 4 - Wbs project phase

\begin{tabular}{|r|l|}
\hline \multicolumn{1}{l|l|}{ WBS } & \multicolumn{1}{|c|}{ PHASE NAME } \\
\hline A. & PHASE 1: Purchase of the coal cauldrons \\
\hline B. & PHASE 2: The choice of a supplier/ work expontent \\
\hline C. & PHASE 3: The breakup of the steam cauldron \\
\hline D. & PHASE 4: The transport of cauldron`s plants \\
\hline E. & PHASE 5: The assembly of the cauldron in the factory in Belgrade \\
\hline F. & PHASE 6: The testing of cauldrons \\
\hline G. & PHASE 7:The project closing \\
\hline
\end{tabular}

The time of the project duration: 4 months

Table 5 - The structure of the costs for cauldron 1:

\begin{tabular}{|l|l|l|}
\hline NB. & THE PHASE OF THE PROJECT & $\begin{array}{l}\text { PLANNED COSTS } \\
\text { (NO VAT) }\end{array}$ \\
\hline 1 & Purchase of the cauldron plant in Stragar & $€ 120,000$ \\
\hline 2 & Breakup of the steam cauldron in Stragar & $€ 127,000$ \\
\hline 3 & Transport of the cauldron`s plant & $€ 38,000$ \\
\hline 4 & Assembly of the cauldron in FHB & $€ 177,000$ \\
\hline 5 & Purchase of the accessories & $€ 230,000$ \\
\hline 6 & Reconstruction of the cauldron from 21t to 25t & $€ 250,000$ \\
\hline 7 & Construction work & $€ 200,000$ \\
\hline 8 & Additional costs (supervisory body + unplanned costs) & $€ 150,000$ \\
\hline 9 & The project closing & $€ 150,000$ \\
\hline & TOTAL: & $€ 1,442,000$ \\
\hline
\end{tabular}

*Source paper factory 
Table 6 - The structure of the costs for cauldron 2:

\begin{tabular}{|l|l|l|}
\hline R.B. & THE PHASE OF THE PROJECT & $\begin{array}{l}\text { PLANNED COSTS } \\
\text { (NO VAT) }\end{array}$ \\
\hline 1 & Purchase of the cauldron`s plant in Berane & $€ 40,000$ \\
\hline 2 & Breakup of the steam cauldron in Berane & $€ 37,000$ \\
\hline 3 & Transport of the cauldron`s plant & $€ 10,000$ \\
\hline 4 & Assembly of the cauldron in FHB & $€ 81,000$ \\
\hline 5 & Purchase of the accessories & $€ 00,000$ \\
\hline 6 & Reconstruction of the cauldron from 21t to 25t & $€ 150,000$ \\
\hline 7 & The construction work & $€ 100,000$ \\
\hline 8 & Additional costs (supervisory body + unplanned costs) & Included in the assembly \\
\hline 9 & The testing of the cauldron & Included in the assembly \\
\hline & TOTAL: & $€ \mathbf{5 1 8 , 0 0 0}$ \\
\hline
\end{tabular}

*Source paper factory

\subsection{Project savings calculations}

The calculations of the savings by transition from gas to solid fuel.

In the next part the calculation of the savings will be illustrated, if we use both cauldrons.

THE PRICES AND THE COMPARISONS:

1) The coal price: the coal price includes transport from diggings to the factory:

- Coal RB Banovići $65 \mathrm{EUR} / \mathrm{t}=7237.75 \mathrm{RSD} / \mathrm{t}$;

- Coal RB Kolubara 78.4 EUR/t = 8729.84 RSD/t.

The gas price is gas $=40 \mathrm{RSD} / \mathrm{Nm}^{3}$, this price is an arithmetic mean

2) The price of ash disposal: this price also includes the disposal on the depot and the transport from the paper factory to the depot, and it amounts to $37 \mathrm{EUR} / \mathrm{t}=4119.95 \mathrm{RSD} / \mathrm{t}$.

3) Labour force: For labour force is planned to include 17 workers: 5 cauldron specialists, 4 cauldron specialists ' assistants, 4 workers for coal and ash transport, 2 locksmiths, 1 headman, 1 chief.

The average gross wage is $65000 \mathrm{RSD} /$ per month. Now we have 8 workers, and for them the same value of gross wage is taken.

4) The price for cauldron maintenance: this price is adopted on experience data basis.

The price of the ongoing maintenance on the monthly level is Co $=155,890.00 \mathrm{RSD} /$ per month.

THE BUDGET OF THE COAL CONSUMPTION - cauldron 1

For the budget of the coal consumption the following input data are used:

- Steam production $D=25 t / h$

- Steam pressure on the caldron exit piz $=42$ bar

- Steam temperature on the caldron exit tiz $=253^{\circ} \mathrm{C}$

- Feed ware pressure (the caldron entrance) pul=46bar (adopted on the experience basis)

- The temperature of the feed water (the caldron s entrance) tul $=105^{\circ} \mathrm{C}$

- The caldron efficiency level $\eta \mathrm{k}=82.5 \%$,

- The values gained by calculating are presented in Table 1.

CALCULATION OF COAL PRODUCTION - cauldron 2

For the budget of the coal consumption the following input data are used:

- Steam production $\mathrm{D}=10 \mathrm{t} / \mathrm{h}$

- The highest allowed pressure $=42 \mathrm{bar}$

- The steam temperature on the caldron exit tiz $=192^{\circ} \mathrm{C}$

- The temperature of the feed water (the caldron entrance) tul $=105^{\circ} \mathrm{C}$

- The caldron efficiency level $\eta \mathrm{k}=82.5 \%$, 
Table 7 - The whole coal consumption

\begin{tabular}{|l|l|l|}
\hline \multicolumn{2}{|l|}{ COAL CONSUMPTION - TOTAL CAULDRON 1 + 2 } \\
\hline Position name: & $\begin{array}{l}\text { Lignit dried nut 15- } \\
30 \mathrm{~mm}\end{array}$ & $\begin{array}{l}\text { Banovići nut 15- } \\
40 \mathrm{~mm}\end{array}$ \\
\hline Wet W (\%) & 23.2 & 21.49 \\
\hline Ash A (\%) & 8,99 & 12.09 \\
\hline Bottom thermal energy Hd(kJ/kg) & $17,567.00$ & $17,000.00$ \\
\hline Coal consumption B(t/h) & 5.69 & 5.88 \\
\hline Coal consumption B(t/daily) & 136.58 & 141.13 \\
\hline Coal consumption $\mathrm{B}(\mathrm{t} / \mathrm{monthly)}$ & 4097.26 & 4233.91 \\
\hline Mass portion of ash Ag (t/daily) & 12.28 & 17.07 \\
\hline Mass portion of ash Ag(t/monthly) & 368.34 & 511.88 \\
\hline
\end{tabular}

*Source paper factory

Table 8 - Savings cauldron $1+2$

\begin{tabular}{|l|l|l|l|}
\hline \multicolumn{5}{|l|}{ SAVINGS CAULDRON $1+2$} & \multicolumn{1}{l|}{} \\
\hline Position name: & Lignit dried & Banovići nut & Gas \\
\hline $\begin{array}{l}\text { The prices of coal and gas (RSD/monthly); } \\
\text { (RSD/Nm3) }\end{array}$ & $35,768,383.38$ & $30,643,965.46$ & $74,592,000.00$ \\
\hline The price of ash disposal (RSD/monthly & $1,517,534.31$ & $2,108,917.05$ & \\
\hline Labour force (RSD/monthly) & $1,105,000.00$ & $1,105,000.00$ & $520,000.00$ \\
\hline The price of cauldron maintenance (RSD/monthly) & $155,890.00$ & $155,890.00$ & \\
\hline Monthly total (RSD/monthly) & $38,546,807.69$ & $34,013,772.51$ & $75.112,000.00$ \\
\hline Gas savings (RSD/monthly) & $36,565,192.31$ & $\mathbf{4 1 , 0 9 8 , 2 2 7 . 4 9}$ & \\
\hline
\end{tabular}

*Source paper factory

Monthly effect amounts to cca $€ 360.000$

The more savings are made by using coal from the "Banovići" mining tank, by cca $17 \%$ in comparison with the coal from "Kolubara".

Criteria for settlement date:

\section{$\mathbf{t}=\mathbf{I} / \mathrm{NP}$}

$\mathrm{t}$-the settlement date in years

I-the total invested means

NP-the annual amount of net effect (net income) from the project

Table 9 - The global projection of total invested means `structure

\begin{tabular}{|l|l|l|}
\hline R.B. & NAME & AMOUNT EUR (no VAT) \\
\hline 1 & Cauldron 1 & $€ 1,442,000$ \\
\hline 2 & Caldron 2 & $€ 518,000$ \\
\hline 3 & Project financing costs & $€ 150,000$ \\
\hline & GRAND TOTAL: & $€ 2,110.000$ \\
\hline
\end{tabular}

\section{$I=2,110.000 €$}

MONTHLY NET EFFECT: $€ 360.000$

ANNUAL NET EFFECT: $€ 4.320 .000$ 
Table 10 - The dynamics of returned invested means preview

\begin{tabular}{|l|l|l|}
\hline Months & \multicolumn{1}{|c|}{$\begin{array}{c}\text { NP-annual amount of } \\
\text { project's net effect }\end{array}$} & \multicolumn{1}{|c|}{$\begin{array}{c}\text { Accumulative annual amount } \\
\text { of project net effect }\end{array}$} \\
\hline 1 & $€ 60,000$ & $€ 360,000$ \\
\hline 2 & $€ 360,000$ & $€ 720,000$ \\
\hline 3 & $€ 360,000$ & $€ 1,080,000$ \\
\hline 4 & $€ 360,000$ & $€ 1,440,000$ \\
\hline 5 & $€ 360,000$ & $€ 2,160,000$ \\
\hline 6 & $€ 360,000$ & $€ 2,520,000$ \\
\hline 7 & $€ 360,000$ & $€ 2,880,000$ \\
\hline 8 & $€ 360,000$ & $€ 3,240,000$ \\
\hline 9 & $€ 360,000$ &
\end{tabular}

$\mathrm{ROI}=5.9$ months

By applying the illustrated formula it can be inferred from the callculations that both caldrons invesments will be paid off in 5.9 months, and detailed calculations are illustrated in the table.

\section{Conclusions and Discussion}

Based on all previously presented, it can be concluded that investing in industrial energetics is a necessary tak for big companies that deal in with process paper production. The boiler rooms represent the basic part of every production and directly influence the prices of end products. According to that, it is necessary to constantly search for better and more profitable solutions in energy-generating products production.

The main aim, i.e., the main hypothesis of this research, is about the usage and adoption of the project managing concept in industrial energetics. This research is used to present an example of successful implementation of this concept in the paper industry, more precisely, in a paper factory. An adequate pre-investing study Is carried out, a lot of project management methods are applied (wbs structure, gantt chart, SWOT analysis, criteria for settlement date, etc.). Also, a significant amount of savings is made by the realization of this project and the settlement date is shorter that one year so we can conclude that the main hypothesis is confirmed through this example.

The emergence of such projects is more and more common, because currently the market conditions dictate the pace of using the most cost-effective energy-generating products, one of them being coal. What is paradoxical is the fact that the 'dirty' and maybe 'archaic' methods for activation of production in factories (coal caldrons) are being welcomed back, and that the gas caldrons are being thrown out and become less represented on the market. Of course, the main motive for all companies is to find the most economic and best sollutions for their sources to supply the production. Such sollutions in industrial energetics are very complex investment projects. The realization of such projects requires a high level of knowledge of project management and industrial energetics. Using the synergy of sciences we get a successful team of people who are necesssary for the realization of one big project, one represented in this research.

Documenting, analysis and evaluation of these projects represent one important segment of the project realization in industrial energetics. Desirable is that after project closing is made an adequate report, where the most important experiences, problems and critical events from the project will be presented. The completed project evaluation will contribute to a more effective adoption of the project management concept, what is illustrated in the first supporting hypothesis. In this research all crucial events on this project have been presented, all problems arising when there is a transition from one to another type of energy-generating products have been noted, e.g., the costs incurred when a new energy-generating product is being introduced. This part is illustrated in more detail in the second and the fourth chapters, where the general conclusion is that the coal is the most economic energy-generating product and it requires engagement of more people to use it. Also, from the ecological point of view, problems arise when obtaining adequate licenses from the state. With this research, the supporting hypothesis is confirmed. 
From the technical and the project points of view, this research presents all the most frequently applied modern project methods, all important details about caldron type, the way of managing this project, cost projection of transition to the new energy-generating product, etc. For example, the information that the utilization of coal from the 'Banovici' mining site in this project is more cost-effective by cca $17 \%$ than that of the coal from 'Kolubara', can be treated as very important information for the products to come in this domain. It can be concluded that this approach of documenting and analysis of these projects is more than desirable and necessary, and that in this way the knowledge basis is being enhanced and the base for the most effective realization of the future projects is being established, where the supporting hypothesis is confirmed.

The modern development of the project management concept will definitely improve a successful project realization in the industrial energetics domain. The spread of this concept in this industry with the adequate formatting of the base will contribute to this concept to be envitable in the future in the execution of such projects.

\section{REFERENCES}

[1] Barroso, J., Barreas, F., \& Ballester, J. (2004). Behavior of a high-capacity steam boiler using heavy fuel oil Part I. High-temperature corrosion. Fuel Processing Technology 86, 89- 105.

[2] Binkiewicz, Kleisley, McMahon, Monacelli, \& Roth. (2008). Natural Gas Conversions of Existing CoalFired Boilers. Babcock \& Wilcox Power Generation Group (str. 5-12). Ohio, USA: Babcock \& Wilcox.

[3] Chuah, K., Tummala, R., \& Nkasu, M. (1995). Project management structures in Hong Kong industries. International Journal of Project Management Vol. 13, 253-257.

[4] Farzana, A., \& Pinnington, A. (2013). Exploring the value of project management: Linking Project Management Performance and Project Success. International Journal of Project Management.

[5] Gulić, M., Brkić, L., \& Perunović, P. (1991). PARNI KOTLOVI. Beograd: Mašinski Fakultet.

[6] Hussain, R., \& Wearne, S. (2005). Problems and needs of project managament in the process and other industries. Trans IChemE, Part A, 372-378.

[7] Jovanović, P., \& Mihić, M. (2006). Upravljanje projektima. Beograd: Fakultet organizacionih nauka.

[8] Kaupp, A. (2009). Energising Sustainable Development. GTZ.

[9] Marković, D., Petrović, D., \& Mihić , M. (2012). Cost-benefit analiza projekata proizvodnje električne energije iz obnovljivih izvora. Management, 64, 39-45.

[10] Mehmod, A., Gale, A., Brown, M., \& Kidd, C. (2008). The development and delivery of an industry led project management professional development programme: A case study in project management education and success management. International Journal of Project Management 26, 223-237.

[11] Mihić, M. (2011). Strateško upravljanje projektima. Zadužbina Andrejević, (str. 118).

[12] Mihić, M., Obradović, V., \& Todoeovic, M. (2014, August). Economic analysis of social services for the elderly in Serbia: two sides of the same coin. Evaluation and Program Planning, 45, 9-21. doi:10.1016/j

[13] Mihić, M., Petrović, D., \& Vučković, A. (2014). Comparative analysis of global trends in energy sustainability. Environmental Engineering and Management Journal, 13, 947-960.

[14] Mihić, M., Petrović, D., Obradović, V., Djurović, D., \& Vučković, A. (2012). Application and Importance of Cost-Benefit Analysis in Energy Efficiency Projects Implemented in Public Buildings The Case of Serbia. Thermal Science, 915-929.

[15] Mihić, M., Petrović, D., Vučković, A., Obradović, V., \& Djurović, D. (2012). Application and Importance of Cost-Benefit Analysis in Energy Efficiency Projects Implemented in Public Buildings: The Case of Serbia. Thermal Science, 16, 915-929.

[16] Mihić, M., Vučković, A., \& Vučković, M. (2012). Upravljanje koristima u projektima energetske efikasnosti u javnim zgradama u Srbiji. Management, 64, 57-65.

[17] Munns, B., \& Bjerimi, K. (1996). The role of project management in achieving project success. International Journal of Project Management Vol. 14, No. 2, 81-87.

[18] Salazar-Aramayo, J., Rodrigues-da-Silveira, R., Rodrigues-de-Almeida, M., \& Neuma de Castro-Dantas, T. (2012). A conceptual model for project management of exploration and production in the oil and gas industry: The case of a Brazilian company. International Journal of Project Management 31, 589601.

[19] Sandenberg, P., \& Soderstrom, M. (2003). Industrial energy efficiency: the need for investment decision support from a manager perspective. Energy Policy, 1623-1634.

[20] Scott-Young, C., \& Samson, D. (2008). Project success and project team management: Evidence from 
capital projects in the process industries. Journal of Operations Management 26, 749-766.

[21] Terrence, C., \& Arzymanow, A. (2003). The maturity of project management in different industries: An investigation into variations between project management models. International Journal of Project Management 21, 471-478.

[22] Too, E. G., \& Weaver, P. (2013). The management of project management: A conceptual framework for project governance. International Journal of Project Management (2013).

[23] Vasquez, J. R., Perez, R., Moriano, S., \& Gonzalez, P. (2008). System identification of steam pressure in a fire-tube boiler. Computers and Chemical Engineering 32, 2839-2848.

[24] Vuckovic, A., Mihić, M., \& Petrović, D. (2013). Strategic Management of Energy Efficiency Project Portfolio in Public Buildings. Tehnika - Menadžment, 943-968.

[25] Wirth, I. (1996). How generic and how industry specific is the project management proffesion? International Journal of Project Management Vol. 14, 7-11.

[26] Worrell, E., Berkel, R., Fengqi, Z., Menke, C., Schae!er, R., \& Williams, R. (2001). Technology transfer of energy efficient technologies in industry: a review of trends and policy issues. Energy Policy, 29-43.

Receieved: October 2014.

Accepted: May 2015.

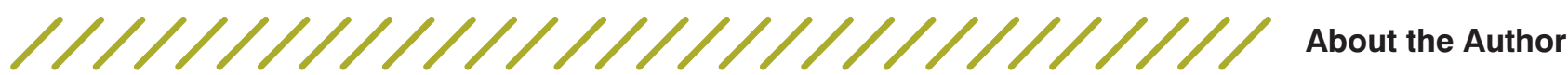

\section{Golub Markovic}

Cardboard Mill Umka, KappaStar Group, 13.oktobra 1 golub.markovic@kappastar.com

Golub Markovic is a PhD candidate at the Faculty of Organizational Sciences, Department of Management, University of Belgrade. The author works as a head of purchasing department at Cardboard Mill Umka which is member of KappaStar Group. He completed his undergraduate and master studies at the Faculty of Organizational Sciences in Belgrade, with the major occupational fields : management and organisation, project management, strategic management.

Marko Mihic
University of Belgrade, Faculty of Organizational Sciences
mihic.marko@fon.rs

Marko Mihic is an associate professor at the Faculty of Organizational Sciences, Management Department. His research interests include Strategic Management, Project Management and Cost-Benefit analysis. He has published 8 books and over 100 peerreviewed papers. As an expert consultant, he has worked extensively for the Serbian government institutions, as well as for several leading national and multinational companies and investors in Serbia.

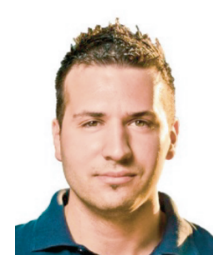

Vladimir Obradovic University of Belgrade, Faculty of Organizational Sciences obradovicv@fon.bg.ac.rs

Vladimir Obradovic works as an assistant professor at the Department of Management and specialized management disciplines. For his research results he has been honored a highest scientific status by the Serbian Ministry of Science. He is a director of YUPMA

Cert - Serbian Project Management Association Certification Body. So far he has published 8 books and over 50 papers in peer-reviewed conferences and journals..
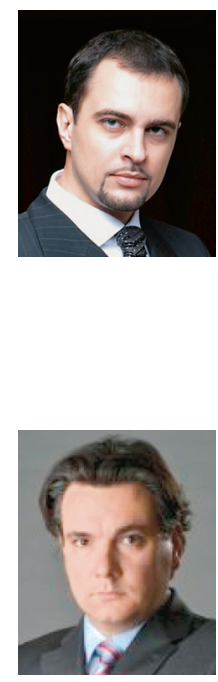